\title{
NO selective reduction by hydrogen on potassium titanate supported palladium catalyst
}

\author{
Landong Li ${ }^{\mathrm{a}, \mathrm{b}}$, Fuxiang Zhang ${ }^{\mathrm{a}}$, Naijia Guan ${ }^{\mathrm{a}, *}$, Ellen Schreier ${ }^{\mathrm{c}}$, Manfred Richter ${ }^{\mathrm{c}, *}$ \\ a Institute of New Catalytic Materials Science, College of Chemistry, Nankai University, Tianjin 300071, PR China \\ ${ }^{\mathrm{b}}$ Research Center for Eco-Environmental Science, Chinese Academy of Science, Beijing 100085, PR China \\ ${ }^{c}$ Leibniz-Institute for Catalysis, Branch Berlin, Richard-Willstätter-Street 12, D-12489 Berlin, Germany
}

\section{A R T I C L E I N F O}

Article history:

Received 26 July 2007

Received in revised form 13 February 2008

Accepted 14 February 2008

Available online 4 March 2008

\section{Keywords:}

Palladium

Titanate

Hydrogen

NO reduction

\begin{abstract}
A B S T R A C T
Potassium titanate $\left(\mathrm{K}_{2} \mathrm{O}-6 \mathrm{TiO}_{2}\right)$ nanowires were successfully prepared by alkali treatment of $\mathrm{TiO}_{2}(79 \%$ anatase, $21 \%$ rutile) under autogenous pressure in a Teflon-lined autoclave at $200{ }^{\circ} \mathrm{C}$. After further modification with 1 wt.\% Pd by wet impregnation, the calcined and pre-reduced $\mathrm{Pd} / \mathrm{K}_{2} \mathrm{O}-6 \mathrm{TiO}_{2}$ catalyst was applied for selective reduction of $\mathrm{NO}_{x}$ by $\mathrm{H}_{2}\left(\mathrm{H}_{2}-\mathrm{SCR}\right)$ under lean conditions, together with $\mathrm{Pd} / \mathrm{Al}_{2} \mathrm{O}_{3}$ and $\mathrm{Pd} / \mathrm{TiO}_{2}$ as reference. The reference catalysts exhibited maximum NO conversion of about $50-60 \%$ at $100-130{ }^{\circ} \mathrm{C}$, but with low $\mathrm{N}_{2}$ selectivity. The $\mathrm{N}_{2}$ selectivity on $\mathrm{Pd} / \mathrm{K}_{2} \mathrm{O}-6 \mathrm{TiO}_{2}$ was considerably high, reaching $80 \%$ at maximum, with only $11 \%$ conversion of the admixed hydrogen reductant. In situ DRIFT spectroscopy revealed surface-fixed nitrates and Pd-bound $\mathrm{NO}$, but no $\mathrm{NH}_{x}$ ad-species. It is concluded, that the beneficial effect of the $\mathrm{K}_{2} \mathrm{O}-6 \mathrm{TiO}_{2}$ support is due mainly to a stabilization of high Pd dispersion with enhanced concentration of $\mathrm{Pd}^{0}-\mathrm{NO}$ intermediates, and due to support alkalinity, that enhances nitrate fixation.
\end{abstract}

(c) 2008 Elsevier B.V. All rights reserved.

\section{Introduction}

Nitrogen oxides, from stationary and transportation sources, are major air pollutants that greatly contribute to the formation of photochemical smog and acid rain [1]. Various post-treatment methods have been attempted for the reduction of $\mathrm{NO}_{x}$ emissions. In the case of stationary sources, the selective catalytic reduction of $\mathrm{NO}_{x}$ by ammonia $\left(\mathrm{NH}_{3}-\mathrm{SCR}\right)$, a state-of-the-art technology for $\mathrm{NO}_{x}$ abatement, has been extensively studied. The vanadia/titaniabased catalysts have already been commercially used in the industrial scale. However, under road conditions, the risk of vanadia emissions and $\mathrm{NH}_{3}$ slip causes safety concerns [2]. Because ammonia synthesis needs hydrogen, it is desirable to use hydrogen directly as $\mathrm{NO}_{x}$ reductant, without intermediate processing to ammonia. Therefore, the selective catalytic reduction of $\mathrm{NO}_{x}$ by hydrogen $\left(\mathrm{H}_{2}-\mathrm{SCR}\right)$, is regarded as good alternative for $\mathrm{NH}_{3}-\mathrm{SCR}$ and is receiving increasing attention.

Supported platinum catalysts are initially found to be active for the $\mathrm{H}_{2}-\mathrm{SCR}$ reaction at low temperatures in 1997 [3]. Subsequently, $\mathrm{Pt} / \mathrm{SiO}_{2}$ [4,5], $\mathrm{Pt} / \mathrm{TiO}_{2}-\mathrm{ZrO}_{2}$ [6], $\mathrm{Pt} / \mathrm{La}_{0.5} \mathrm{Ce}_{0.5} \mathrm{MnO}_{3}$ [7], Pt/ MFI $[8,9]$ and $\mathrm{Pt} / \mathrm{Mg}-\mathrm{Al}-\mathrm{O}[10]$ have been reported to be promising catalysts for $\mathrm{H}_{2}-\mathrm{SCR}$ reaction. More recently, supported palladium catalysts, such as $\mathrm{Pd} / \mathrm{TiO}_{2}$ [11], $\mathrm{Pd} / \mathrm{Al}_{2} \mathrm{O}_{3}$ [12], $\mathrm{Pd} / \mathrm{V}_{2} \mathrm{O}_{5} / \mathrm{Al}_{2} \mathrm{O}_{3}$ [13]

\footnotetext{
* Corresponding authors.

E-mail addresses: guannj@nankai.edu.cn (N. Guan), manfred.richter@catalysis.de (M. Richter).
}

and $\mathrm{Pd} / \mathrm{TiO}_{2} / \mathrm{Al}_{2} \mathrm{O}_{3}$ [14] are also reported to be highly active in $\mathrm{H}_{2}$-SCR reaction. However, the activity of supported platinum and palladium catalysts for NO reduction is usually achieved at the expense of a high hydrogen consumption (usually 100\%), that means, most of the hydrogen reacts with excess oxygen in the reaction system directly to water. Moreover, the formation of the undesired byproduct $\mathrm{N}_{2} \mathrm{O}$ is a serious problem to be solved.

In this work, potassium titanate supported palladium $\left(\mathrm{Pd} / \mathrm{K}_{2} \mathrm{O}-\right.$ $6 \mathrm{TiO}_{2}$ ) is described as a promising alternative catalyst formulation for the $\mathrm{H}_{2}$-SCR reaction, with good catalytic performance at a comparatively low hydrogen consumption. The catalyst exhibits good activity and $\mathrm{N}_{2}$ selectivity, as compared with $\mathrm{Pd} / \mathrm{TiO} \mathrm{O}_{2}$ and $\mathrm{Pd} / \mathrm{Al}_{2} \mathrm{O}_{3}$. A detailed structural and textural characterization was performed using XRD, Raman spectroscopy, TEM, $\mathrm{N}_{2}$ adsorption, and TPR. The Pd dispersion was determined by $\mathrm{H}_{2}$ titration. Surface species and intermediates of $\mathrm{NO}_{x}$ conversion were studied by means of in situ diffuse reflectance infrared Fourier transform spectroscopy (DRIFTS). Key points of the reaction mechanism will be discussed.

\section{Experimental}

\subsection{Catalyst preparation}

Potassium titanate with nanorod morphology was prepared from $\mathrm{TiO}_{2}$ (Degussa $\mathrm{P} 25$, anatase $79 \%$, rutile $21 \%$ ) by an alkali treatment, as described in reference $[15,16]$. In a typical synthesis, $10 \mathrm{~g}$ 
$\mathrm{TiO}_{2}$ powder and $100 \mathrm{~mL} \mathrm{KOH}$ solution $(10 \mathrm{M})$ were mixed together. After vigorous stirring for about $2 \mathrm{~h}$, the mixture was transferred into a Teflon-lined autoclave $(125 \mathrm{~mL})$ and heated at $200{ }^{\circ} \mathrm{C}$ for $48 \mathrm{~h}$. The precipitate was filtrated and thoroughly washed with distilled water until $\mathrm{pH}<9$. Then, the precipitate was dried at $80^{\circ} \mathrm{C}$ overnight and calcined at $400{ }^{\circ} \mathrm{C}$ in flowing air for $4 \mathrm{~h}$.

The as-synthesized potassium titanate, together with $\mathrm{TiO}_{2}$ (Degussa P25) and $\gamma-\mathrm{Al}_{2} \mathrm{O}_{3}$ (Tosoh Co.), was used as catalyst support. Palladium was introduced into the supports by wet impregnation with an aqueous palladium(II) chloride solution sufficient to yield $1 \%$ Pd loading. After impregnation, the catalysts were again dried overnight and calcined at $400{ }^{\circ} \mathrm{C}$ in flowing air for $4 \mathrm{~h}$.

\subsection{Catalyst characterization}

Powder X-ray diffraction (XRD) measurements were carried out on the samples using a Rigaku D/max 2500 diffractometer, equipped with a graphite monochromator and using $\mathrm{Cu} \mathrm{K} \alpha$ radiation. Raman spectroscopy was carried out with a Renishaw InVia Raman Spectrometer. Spectra were obtained with the green line of an Ar-ion laser (514.53 nm) in micro-Raman configuration.

Transmission electron microscopy (TEM) images of samples were acquired on a Tecnai $G^{2} 20$ S-TWIN transmission electron microscope at an accelerate voltage of $200 \mathrm{kV}$.

The textural properties of catalysts were analyzed by low-temperature $\mathrm{N}_{2}$ adsorption/desorption using a Quantachrome NOVA1200 gas absorption analyzer and the specific surface areas were calculated using the BET equation.

$\mathrm{H}_{2}$-TPR was carried out in a microreactor using $50 \mathrm{mg}$ of sample for each run. The sample was pretreated in flowing air at $400{ }^{\circ} \mathrm{C}$ for $2 \mathrm{~h}$ and then cooled down to $50^{\circ} \mathrm{C}$ in flowing He. At constant temperature of $50{ }^{\circ} \mathrm{C}$, the flow of $\mathrm{H}_{2} / \mathrm{He}\left(5 \% \mathrm{H}_{2}, 30 \mathrm{~mL} \mathrm{~min}^{-1}\right)$ was switched to the sample, and after $30 \mathrm{~min}$ the temperature-programmed reduction was started from $50{ }^{\circ} \mathrm{C}$ to $250{ }^{\circ} \mathrm{C}$ with a temperature ramp of $5^{\circ} \mathrm{C} \mathrm{min}-1$. The consumption of the reducing agent $\mathrm{H}_{2}$ was measured on-line by a gas chromatograph equipped with a TCD.

\subsection{Catalytic testing}

The selective catalytic reduction of NO by hydrogen was performed in a fixed-bed flow microreactor at atmospheric pressure. Typically, $0.1 \mathrm{~g}$ of sample (sieve fraction, $0.25-0.5 \mathrm{~mm}$ ) was placed in a quartz reactor ( $4 \mathrm{~mm}$ i.d.) and pretreated in $\mathrm{H}_{2} / \mathrm{He}\left(0.1 \% \mathrm{H}_{2}\right.$ ) at $400{ }^{\circ} \mathrm{C}$ for $1 \mathrm{~h}$. After cooling to $50^{\circ} \mathrm{C}$ in He, the reactant gas mixture (1000 ppm NO, $5000 \mathrm{ppm} \mathrm{H}_{2}, 5 \% \mathrm{O}_{2}$, He balance) was fed to the reactor. The total flow rate of the gas mixture was $100 \mathrm{~mL} \mathrm{~min}^{-1}$, corresponding to a GHSV of $60,000 \mathrm{~h}^{-1}$. The steady-state tests were conducted isothermally every $25^{\circ} \mathrm{C}$ from $50^{\circ} \mathrm{C}$ to $300^{\circ} \mathrm{C}$. The reactant and product gas composition was analyzed on-line using a gas chromatograph (HP 6890 series) equipped with a TCD. A HP-PLOT MoleSieve column served for separation of $\mathrm{H}_{2}, \mathrm{~N}_{2}, \mathrm{O}_{2}$, and a Poraplot $\mathrm{Q}$ column for the separation of $\mathrm{N}_{2} \mathrm{O}$ and NO. Simultaneously, the exit stream composition was continuously analyzed by a multi-gas sensor Multor 610 (Maihak, Germany) equipped with a non-dispersive infrared channel for $\mathrm{NO}$, and a $\mathrm{NO}_{2}-\mathrm{NO}$ converter reducing $\mathrm{NO}_{2}$ to $\mathrm{NO}$ over a molybdenum catalyst. The difference between $\mathrm{NO} / \mathrm{NO}_{2}$ and $\mathrm{NO}$ concentration gives the $\mathrm{NO}_{2}$ content. The nitrogen balance was calculated using the following equation: $[\mathrm{NO}]_{\text {inlet }}=[\mathrm{NO}]_{\text {outlet }}+2\left[\mathrm{~N}_{2} \mathrm{O}\right]_{\text {outlet }}+2\left[\mathrm{~N}_{2}\right]_{\text {outlet }}+\left[\mathrm{NO}_{2}\right]_{\text {outlet. }}$ This $\mathrm{N}$-balance was found to be $>95 \%$ for all experiments. The NO conversion is calculated as $\mathrm{X}_{\mathrm{NO}}=\left([\mathrm{NO}]_{\text {inlet }}-[\mathrm{NO}]_{\text {outlet }}\right) /[\mathrm{NO}]_{\text {inlet }}$ and the $\mathrm{H}_{2}$ conversion as $\mathrm{X}_{\mathrm{H} 2}=\left(\left[\mathrm{H}_{2}\right]_{\text {inlet }}-\left[\mathrm{H}_{2}\right]_{\text {outlet }}\right) /\left[\mathrm{H}_{2}\right]_{\text {inlet }}$. The $\mathrm{N}_{2}$ selectivity is calculated as $\mathrm{S}_{\mathrm{N} 2}=2^{*}\left[\mathrm{~N}_{2}\right] /\left([\mathrm{NO}]_{\text {inlet }}-[\mathrm{NO}]_{\text {outlet }}\right)$, while the $\mathrm{N}_{2} \mathrm{O}$ and $\mathrm{NO}_{2}$ selectivity is calculated as $\mathrm{S}_{\mathrm{N} 2 \mathrm{O}}=2^{*}\left[\mathrm{~N}_{2} \mathrm{O}\right] /$
$\left([\mathrm{NO}]_{\text {inlet }}-[\mathrm{NO}]_{\text {outlet }}\right)$ and $\mathrm{S}_{\mathrm{NO} 2}=\left[\mathrm{NO}_{2}\right] /\left([\mathrm{NO}]_{\text {inlet }}-[\mathrm{NO}]_{\text {outlet }}\right)$, respectively. The $\mathrm{N}_{2}$ yield is calculated as $\mathrm{Y}_{\mathrm{NO}}=2^{*}\left[\mathrm{~N}_{2}\right] /[\mathrm{NO}]_{\text {inlet }}$.

\subsection{DRIFT studies}

DRIFT studies were performed on the spectrometer FTS-60A (BIO-RAD) by using a diffuse reflectance attachment (HARRICK) equipped with a reaction chamber. A number of 256 single beam spectra had been co-added at a resolution of $4 \mathrm{~cm}^{-1}$ and the spectra were presented as absorbance function referred to adequate background spectra. For the in situ DRIFT measurements all catalysts were used as powders (about $75 \mathrm{mg}$ ). Prior to the reduction of NO all catalysts were pretreated in the following way: heating in $\mathrm{H}_{2} / \mathrm{He}\left(0.1 \% \mathrm{H}_{2}\right)$ at a rate of $10{ }^{\circ} \mathrm{C} \mathrm{min}^{-1}$ up to $400{ }^{\circ} \mathrm{C}$ and holding at $400{ }^{\circ} \mathrm{C}$ for $1 \mathrm{~h}$, then cooling down to $80^{\circ} \mathrm{C}$. Subsequently, NO reduction was started under the following feed mixtures: NO (2000 ppm), $\mathrm{H}_{2}$ (1\%), $\mathrm{O}_{2}$ (10\%) (balance $\mathrm{He}$ ) using a total flow of $40 \mathrm{~mL} \mathrm{~min}^{-1}$ at $80^{\circ} \mathrm{C}$. After holding this temperature for $20 \mathrm{~min}$, it was stepwise increased to the next temperature at the heating rate of $10^{\circ} \mathrm{C} \mathrm{min}^{-1}$. The DRIFT spectra were recorded every $25^{\circ} \mathrm{C}$ (from 80 to $255^{\circ} \mathrm{C}$ ) after $20 \mathrm{~min}$ of steady-state reaction.

\section{Results and discussion}

\subsection{Catalyst characterization}

The XRD pattern of as-synthesized sample $\mathrm{K}_{2} \mathrm{O}-6 \mathrm{TiO}_{2}$ is shown in Fig. 1, where all diffraction lines are in good agreement with those of standard pattern for monoclinic $\mathrm{K}_{2} \mathrm{Ti}_{6} \mathrm{O}_{13}$ (space group: C2 $/ \mathrm{m}$; lattice constants: $a=1.5593 \mathrm{~nm}, b=0.3796 \mathrm{~nm}, c=0.9108$ $\mathrm{nm}$; JCPDS \# 40-0403). The structure of the sample is further characterized by Raman spectroscopy, as shown in Fig. 2. Raman bands at $280,390,450,650$ and $860 \mathrm{~cm}^{-1}$ can be observed, which agree with the characteristic bands of $\mathrm{K}_{2} \mathrm{Ti}_{6} \mathrm{O}_{13}$ [17]. The band at $900 \mathrm{~cm}^{-1}$ is attributed to the four coordinated Ti-O stretching modes that stuck out into the interlayer spaces [18]. Notably, the as-synthesized $\mathrm{K}_{2} \mathrm{Ti}_{6} \mathrm{O}_{13}$ is also recognized as $\mathrm{K}_{2} \mathrm{O}-6 \mathrm{TiO}_{2}$, a type of compounds with potassium inserting the layer of $\mathrm{TiO}_{2}$ [19].

The TEM image of as-synthesized potassium titanate in Fig. 3 shows the structure of nanorods with narrow size distribution. The uniform diameters are about $10 \mathrm{~nm}$, and the lengths amount to more than $100 \mathrm{~nm}$. The morphology of nanorods is well preserved after Pd impregnation and calcination as shown in Fig. 4. Moreover, no bulk Pd can be observed, owing to the good

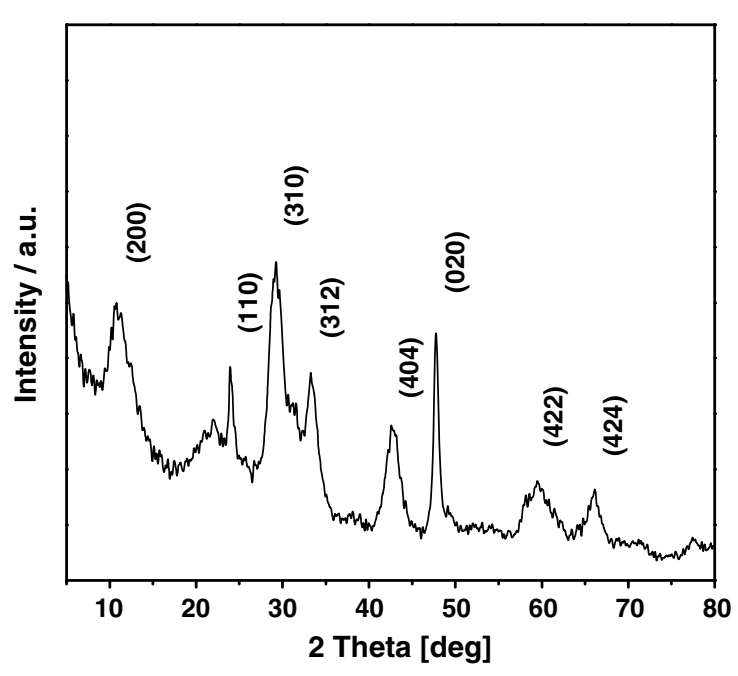

Fig. 1. XRD patterns of as-synthesized potassium titanate. 


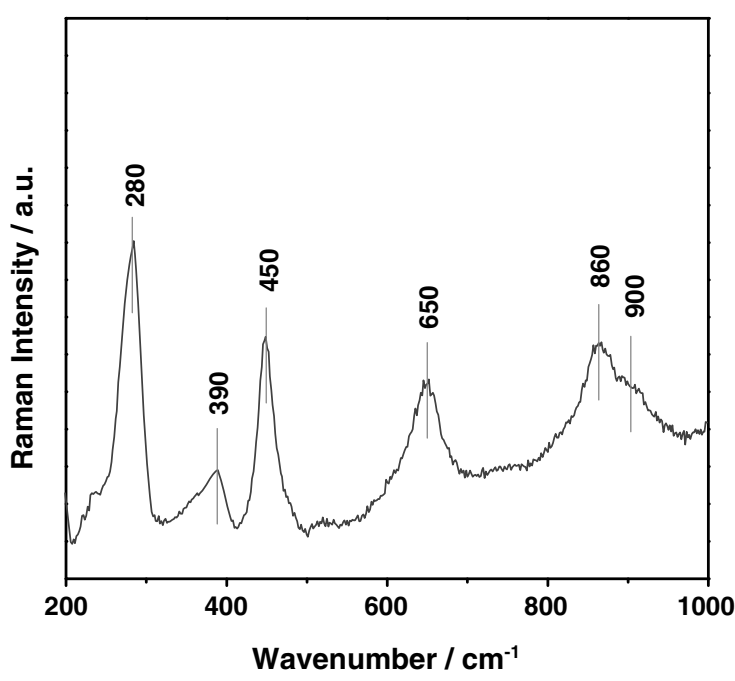

Fig. 2. Raman spectra of as-synthesized potassium titanate.

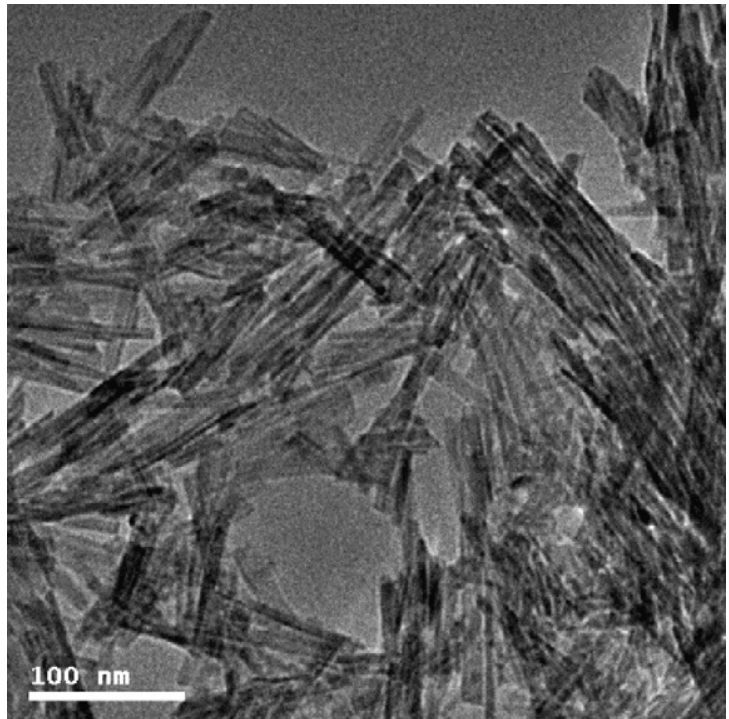

Fig. 3. TEM image of as-synthesized potassium titanate.

dispersion of Pd species (83\%) as determined by $\mathrm{H}_{2}$ chemisorption (Table 1). Some textural properties of $\mathrm{Pd} / \mathrm{K}_{2} \mathrm{O}-6 \mathrm{TiO}_{2}, \mathrm{Pd} / \mathrm{TiO}_{2}$ and $\mathrm{Pd} / \mathrm{Al}_{2} \mathrm{O}_{3}$ are summarized in Table 1 .

The $\mathrm{H}_{2}$-TPR profiles of $\mathrm{Pd} / \mathrm{K}_{2} \mathrm{O}-6 \mathrm{TiO}_{2}, \mathrm{Pd} / \mathrm{TiO}_{2}$, and $\mathrm{Pd} / \mathrm{Al}_{2} \mathrm{O}_{3}$ are shown in Fig. 5. The main reduction of $\mathrm{Pd}$ on $\mathrm{TiO}_{2}$ takes places at temperatures lower than $50{ }^{\circ} \mathrm{C}$, so that no distinct reduction peak could be recorded. In the case of $\mathrm{Pd} / \mathrm{Al}_{2} \mathrm{O}_{3}$ and $\mathrm{Pd} / \mathrm{K}_{2} \mathrm{O}-6 \mathrm{TiO}_{2}$, reduction peaks are observed at $130{ }^{\circ} \mathrm{C}$ and $160{ }^{\circ} \mathrm{C}$, respectively. From the comparison between $\mathrm{Pd} / \mathrm{TiO}_{2}$ and $\mathrm{Pd} / \mathrm{K}_{2} \mathrm{O}-6 \mathrm{TiO}_{2}$, it is believed that the addition of $\mathrm{K}_{2} \mathrm{O}$ significantly retards the reduction of $\mathrm{Pd}^{2+}$, similar to the results reported by $\mathrm{Qi}$ et al. [14] and Zhu et al. [20].

\section{2. $\mathrm{H}_{2}-\mathrm{SCR}$ of $\mathrm{NO}_{x}$}

The performance of $\mathrm{Pd} / \mathrm{TiO}_{2}, \mathrm{Pd} / \mathrm{Al}_{2} \mathrm{O}_{3}$ and $\mathrm{Pd} / \mathrm{K}_{2} \mathrm{O}-6 \mathrm{TiO}_{2}$ catalysts is shown in Fig. 6 . The highest $\mathrm{NO}$ conversion can be observed on $\mathrm{Pd} / \mathrm{TiO}_{2}\left(60 \%\right.$, at $\left.104{ }^{\circ} \mathrm{C}\right)$, followed by $\mathrm{Pd} / \mathrm{Al}_{2} \mathrm{O}_{3}\left(53 \%\right.$, at $\left.128{ }^{\circ} \mathrm{C}\right)$ and $\mathrm{Pd} / \mathrm{K}_{2} \mathrm{O}-6 \mathrm{TiO}_{2}\left(41 \%\right.$, at $\left.164^{\circ} \mathrm{C}\right)$, as shown in Fig. 6 . Whereas the $\mathrm{H}_{2}$ conversion reaches $100 \%$ on $\mathrm{Pd} / \mathrm{TiO}_{2}$ and $\mathrm{Pd} / \mathrm{Al}_{2} \mathrm{O}_{3}$ at the

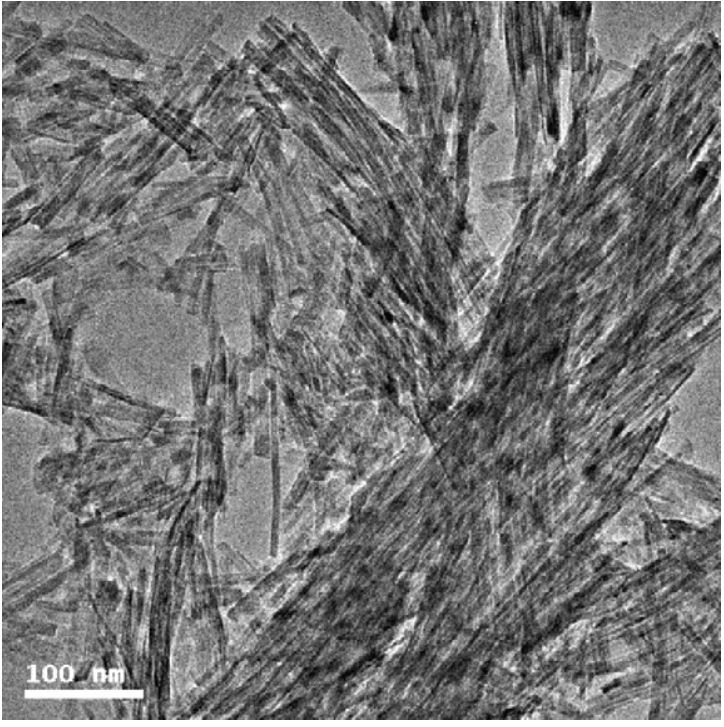

Fig. 4. TEM image of potassium titanate supported palladium catalyst.

Table 1

Textural properties of Pd-based catalysts

\begin{tabular}{lcll}
\hline Catalyst $^{\mathrm{a}}$ & Surface area $\left(\mathrm{m}^{2} \mathrm{~g}^{-1}\right)$ & Pd loading $(\%)^{\mathrm{b}}$ & Pd dispersion $(\%)^{\mathrm{c}}$ \\
\hline $\mathrm{Pd} / \mathrm{TiO}_{2}$ & 25.7 & 0.94 & 59 \\
$\mathrm{Pd} / \mathrm{Al}_{2} \mathrm{O}_{3}$ & 221.8 & 0.95 & 66 \\
$\mathrm{Pd} / \mathrm{K}_{2} \mathrm{O}-6 \mathrm{TiO}_{2}$ & 182.6 & 0.92 & 83 \\
\hline
\end{tabular}

a Treated in $\mathrm{H}_{2} / \mathrm{He}$ for $1 \mathrm{~h}$ at $400^{\circ} \mathrm{C}$.

b By weight.

c Determined by $\mathrm{H}_{2}$ chemisorption and dispersion is calculated as [H uptake]/[Pd loading].

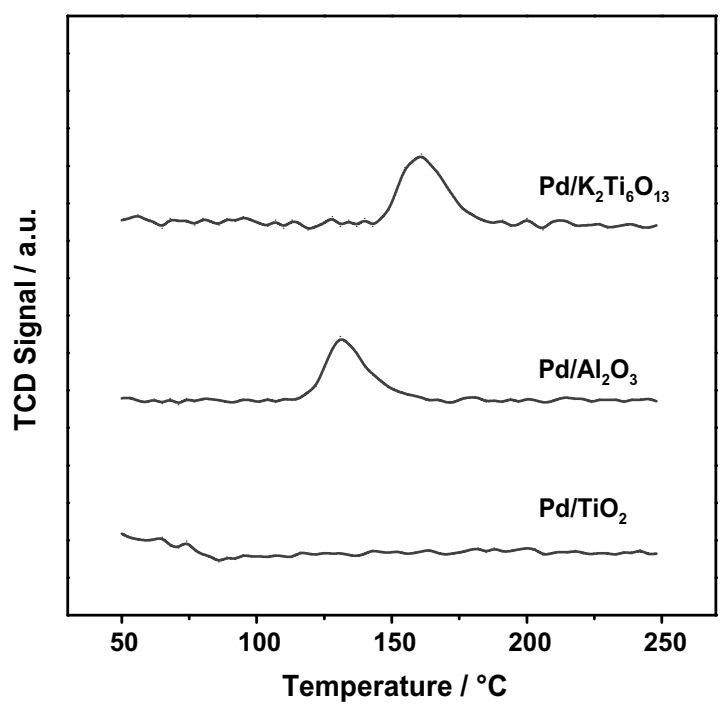

Fig. 5. $\mathrm{H}_{2}-\mathrm{TPR}$ profiles of supported palladium catalysts.

temperature where the maximal NO conversion is achieved (Fig. 6b), only $11 \%$ of admixed $\mathrm{H}_{2}$ is converted on $\mathrm{Pd} / / \mathrm{K}_{2} \mathrm{O}-6 \mathrm{TiO}_{2}$ at the temperature of maximal NO conversion. Obviously, the undesired reaction between $\mathrm{H}_{2}$ and $\mathrm{O}_{2}\left(\mathrm{H}_{2}+\mathrm{O}_{2} \rightarrow \mathrm{H}_{2} \mathrm{O}\right)$ is greatly retarded on $\mathrm{Pd} / \mathrm{K}_{2} \mathrm{O}-6 \mathrm{TiO}_{2}$. This means, $\mathrm{H}_{2}$ acts more selective for the reduction of $\mathrm{NO}$ on $\mathrm{Pd} / \mathrm{K}_{2} \mathrm{O}-6 \mathrm{TiO}_{2}$. The $\mathrm{N}_{2}$ selectivity on the catalysts varies with reaction temperature, as shown in Fig. $6 \mathrm{c}$, but is significantly higher on $\mathrm{Pd} / \mathrm{K}_{2} \mathrm{O}-6 \mathrm{TiO}_{2}$ than on $\mathrm{Pd} / \mathrm{TiO}_{2}$ and $\mathrm{Pd} /$ 

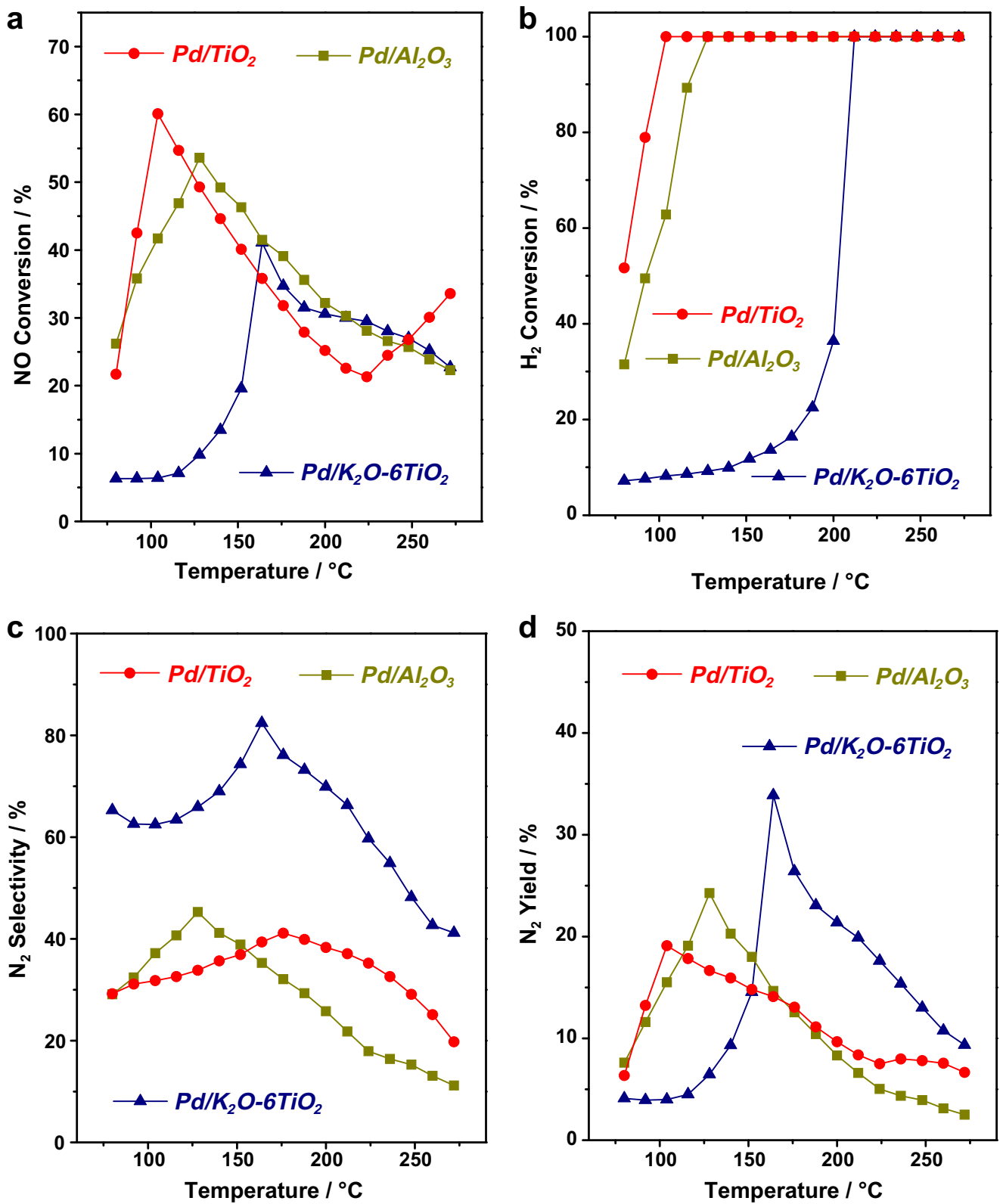

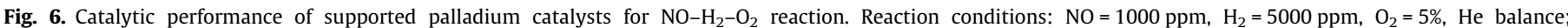
GHSV $=60,000 \mathrm{~h}^{-1}$.

$\mathrm{Al}_{2} \mathrm{O}_{3}$. Finally, the $\mathrm{N}_{2}$ yield over $\mathrm{Pd} / \mathrm{K}_{2} \mathrm{O}-6 \mathrm{TiO}_{2}$ is superior to the reference catalysts at the temperature window $160-260{ }^{\circ} \mathrm{C}$.

The activity of the support (not shown) is lower than $10 \%$ NO conversion up to reaction temperatures of $200{ }^{\circ} \mathrm{C}$, with moderate $\mathrm{H}_{2}$ oxidation between 80 and $164{ }^{\circ} \mathrm{C}(15 \%$ at maximum). However, it must be stated, that the support material is capable to catalyze the deNOx reaction at temperatures higher than $200{ }^{\circ} \mathrm{C}$ with maximum NO conversion of nearly $20 \%$ and about $50 \% \mathrm{~N}_{2}$ selectivity at $275{ }^{\circ} \mathrm{C}$, under complete $\mathrm{H}_{2}$ consumption. These reactivity characteristics are comparable to the performance of the $\mathrm{Pd} / \mathrm{K}_{2} \mathrm{O}-6 \mathrm{TiO}_{2}$ catalyst at temperatures beyond $200^{\circ} \mathrm{C}$. Therefore, the reaction at temperatures higher than $200{ }^{\circ} \mathrm{C}$ benefits from the influence of the support.

A detailed analysis of the product selectivity profile of $\mathrm{Pd} / \mathrm{K}_{2} \mathrm{O}-$ $6 \mathrm{TiO}_{2}$ is displayed in Fig. 7. $\mathrm{N}_{2} \mathrm{O}$ and $\mathrm{NO}_{2}$ are observed as products, besides $\mathrm{N}_{2}$. It is striking that the $\mathrm{N}_{2}$ and $\mathrm{N}_{2} \mathrm{O}$ selectivity exhibit a mirror-like dependence on the reaction temperature with a sharp inversion point at $160-165^{\circ} \mathrm{C}$. These profiles indicate that both products are competitively formed from the same intermediate. Anticipating results of DRIFT spectroscopy (see Section 3.3) the most abundant intermediates are surface-fixed nitrates.

\subsection{DRIFT studies}

DRIFT spectra obtained under reaction conditions over $\mathrm{Pd} / \mathrm{K}_{2} \mathrm{O}-$ $6 \mathrm{TiO}_{2}$ at different temperatures are shown in Fig. 8 . At $80^{\circ} \mathrm{C}$, strong bands at 1605,1585 and $1370 \mathrm{~cm}^{-1}$ as well as some weak bands at 1750,1300 and $1260 \mathrm{~cm}^{-1}$ have been observed. The bands at 1605 and $1260 \mathrm{~cm}^{-1}$ are assigned to bridging nitrate species on the $\mathrm{K}_{2} \mathrm{O}-6 \mathrm{TiO}_{2}$ support, while the bands at 1585 and $1300 \mathrm{~cm}^{-1}$ are assigned to chelating nitrate species on the $\mathrm{K}_{2} \mathrm{O}-6 \mathrm{TiO}_{2}$ support [21,22]. The multi-bands centered at $1370 \mathrm{~cm}^{-1}(1340-1400$ $\mathrm{cm}^{-1}$ ) are assigned to water-solvated nitrate species, as suggested by Goodman et al. [23]. The weak band at $1750 \mathrm{~cm}^{-1}$ may be as- 


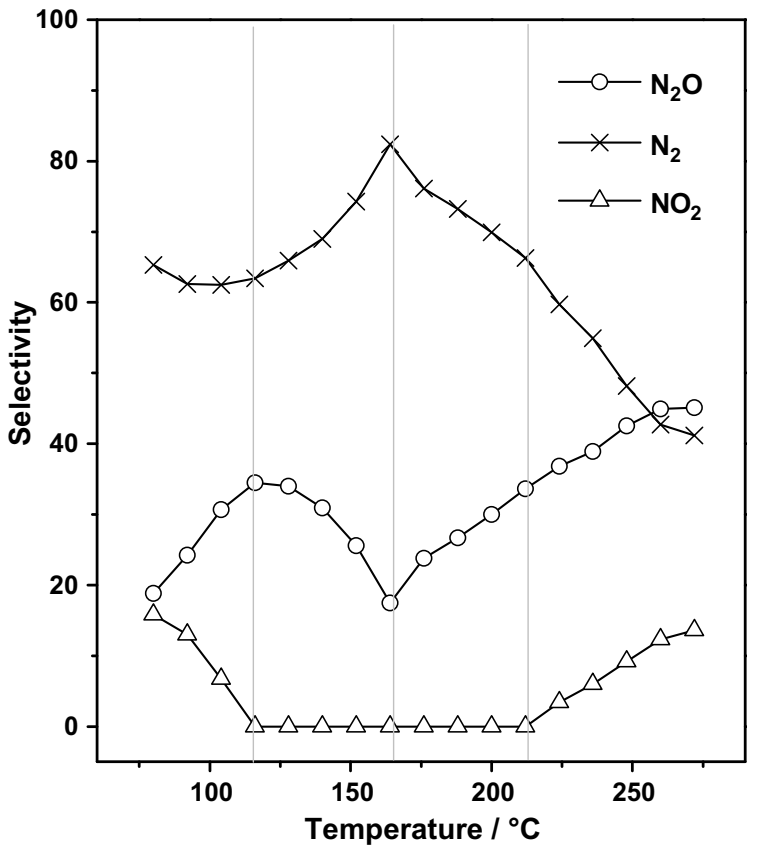

Fig. 7. Product selectivity for $\mathrm{NO}-\mathrm{H}_{2}-\mathrm{O}_{2}$ reaction over $\mathrm{Pd} / \mathrm{K}_{2} \mathrm{O}-6 \mathrm{TiO}_{2}$ catalyst.

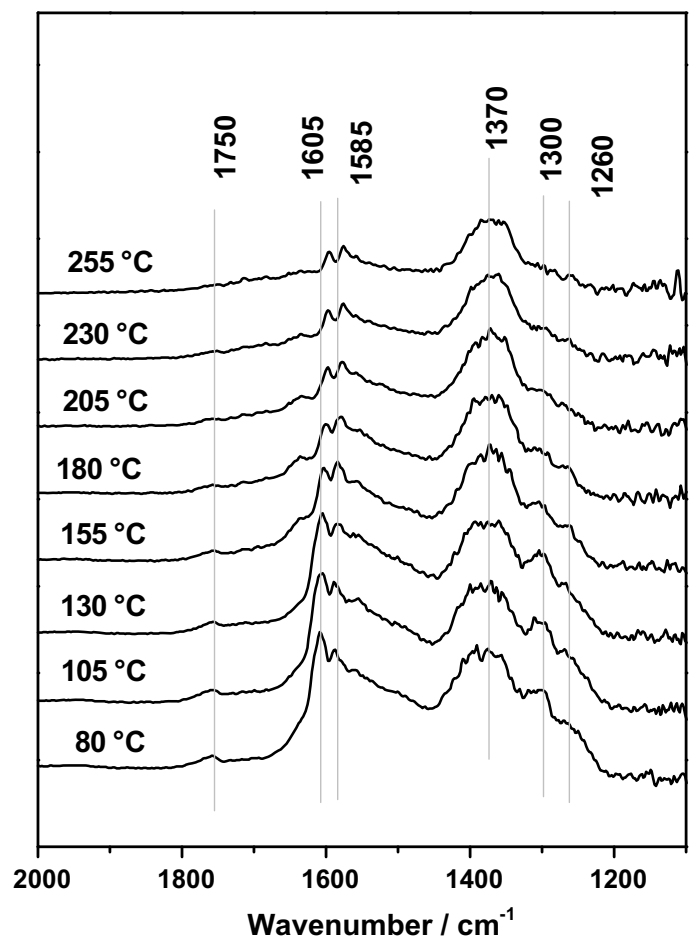

Fig. 8. DRIFTS study of adsorbed species formed on surface of $\mathrm{Pd} / \mathrm{K}_{2} \mathrm{O}-6 \mathrm{TiO}_{2}$ catalyst under $\mathrm{NO}-\mathrm{H}_{2}-\mathrm{O}_{2}$ reaction condition: $2000 \mathrm{ppm} \mathrm{NO}+1 \% \mathrm{H}_{2}+10 \% \mathrm{O}_{2}$ with $\mathrm{He}$ balance.

signed to linear $\mathrm{Pd}^{0}-\mathrm{NO}$ species $[11,14]$, i.e., gaseous NO adsorbs on the surface of Pd, with no band dissociation [24].

With increasing temperatures, the intensity of the IR band associated with linear $\mathrm{Pd}^{0}-\mathrm{NO}$ species decreased gradually and, eventually, disappeared at $180^{\circ} \mathrm{C}$. The intensities of IR bands associated with various coordinated nitrates on the $\mathrm{K}_{2} \mathrm{O}-6 \mathrm{TiO}_{2}$ support increased first to a maximum (at $155^{\circ} \mathrm{C}$ ) and then began to decrease with increasing temperatures. The IR bands corresponding to water-solvated nitrate species remained unchanged over the whole temperature range.

\subsection{Mechanism consideration}

It is known that fixation of $\mathrm{NO}$ in the presence of excess $\mathrm{O}_{2}$ on noble metals as well as support oxides occurs in form of surface nitrates which are reactive towards $\mathrm{H}_{2}$ [6]. By dissociation of $\mathrm{H}_{2}$, the noble metal supplies $\mathrm{H}$ which reacts with nitrates species located on the support. Reduction of the surface species should (desirably) stop at the stage of $\mathrm{N}_{2}$, but can also lead to $\mathrm{NH}_{3}$ [12], according to the catalyst system, feed composition and reaction conditions. DRIFT spectroscopic studies of the $\mathrm{NO}-\mathrm{H}_{2}-\mathrm{O}_{2}$ reaction on $\mathrm{Pd} / \mathrm{Al}_{2} \mathrm{O}_{3}$ and $\mathrm{Pd} / \mathrm{TiO}_{2}$ catalysts revealed adsorbed $\mathrm{NH}_{x}$ species as intermediates that enable an in situ $\mathrm{NH}_{3}-\mathrm{SCR}$ reaction route $[11,12]$. These species could not be observed during $\mathrm{N}_{2}-\mathrm{SCR}$ on the present catalysts, probably, owing to the redox properties of the feed $\left(\mathrm{O}_{2} / \mathrm{H}_{2}=10\right)$.

For comparing the catalytic and DRIFT results, it should be noted that the present findings relate to the catalyst used after pre-reduction with $\mathrm{H}_{2}$ at $400{ }^{\circ} \mathrm{C}$. After pre-reduction at $400{ }^{\circ} \mathrm{C}$, $\mathrm{Pd}^{2+}$ is converted to $\mathrm{Pd}^{0}$ (vide TPR). Nevertheless, the palladium dispersion is kept as high as $83 \%$ (Table 1), i.e., palladium is present in a nearly atomic dispersion. Therefore, no Pd clusters are detectable by TEM (Fig. 4). Interaction of $\mathrm{Pd}^{0}$ with $\mathrm{NO}$ leads to $\mathrm{Pd}^{0}-\mathrm{NO}$ species as revealed by DRIFTS (Fig. 8). Simultaneously, gaseous $\mathrm{NO}$ reacts with $\mathrm{O}_{2}$ to $\mathrm{NO}_{2}$ and, consecutively, to surface nitrates, which could preferentially be fixed to basic sites $\left(\mathrm{K}_{2} \mathrm{O}\right)$ of the support, similar to the $\mathrm{NO}_{x}$ storage process [25].

Whereas for $\mathrm{Pd} / \mathrm{Al}_{2} \mathrm{O}_{3}$ and $\mathrm{Pd} / \mathrm{TiO}_{2}$ the complete consumption of $\mathrm{H}_{2}$ coincides with the maximum of $\mathrm{NO}$ conversion as known from literature data [12], the consumption of $\mathrm{H}_{2}$ is only about $11 \%$ at maximum $\mathrm{NO}$ conversion for sample $\mathrm{Pd} / \mathrm{K}_{2} \mathrm{O}-6 \mathrm{TiO}_{2}$.

Importantly, the $\mathrm{Pd} / \mathrm{K}_{2} \mathrm{O}-6 \mathrm{TiO}_{2}$ catalyst contains zero-valent $\mathrm{Pd}$ after pre-reduction at $400{ }^{\circ} \mathrm{C}$. Since the activation energy for oxygen dissociation is higher for Pd than for PdO [26], it is concluded that the low percentage of $\mathrm{H}_{2}$ oxidation within the activity range between 80 and $164{ }^{\circ} \mathrm{C}$ is caused by poor oxygen activation. Presumably, $\mathrm{NO}_{2}$ (and surface nitrates) are formed from $\mathrm{Pd}^{0}-\mathrm{NO}$ and gaseous $\mathrm{O}_{2}$. With temperature increase, the concentration of $\mathrm{Pd}^{0}-\mathrm{NO}$ decreases and $\mathrm{Pd}^{0}$ is oxidized. Indeed, after reaction at $275{ }^{\circ} \mathrm{C}$, the catalyst contains $\mathrm{Pd}^{2+}$ as revealed by XPS measurements (not shown). The reaction temperature of $164{ }^{\circ} \mathrm{C}$ seems to indicate a modification of the mechanism. Whereas a low-temperature route is characterized by $\mathrm{H}$-assisted dissociation of NO dominating on $\mathrm{Pd}^{0}$ sites, a high-temperature route is accomplished by $\mathrm{H}$-assisted reduction of nitrates on the support. $\mathrm{NO}_{2}$ and $\mathrm{N}_{2} \mathrm{O}$ is produced by thermal decomposition of surface nitrates [27], with deterioration of $\mathrm{N}_{2}$ selectivity. Further investigations are necessary to clarify details of the mechanism of the complex catalyst system.

\section{Conclusion}

The $\mathrm{Pd} / \mathrm{K}_{2} \mathrm{O}-6 \mathrm{TiO}_{2}$ catalyst exhibits good deNOx behavior in the $\mathrm{NO}-\mathrm{H}_{2}-\mathrm{O}_{2}$ reaction under lean conditions, where maximum conversion of $\mathrm{NO}$ can be achieved at comparatively low consumption of the $\mathrm{H}_{2}$ reductant. Characterization data and in situ DRIFT spectroscopy revealed that $\mathrm{Pd}^{0}$ is stabilized in high dispersion, and actually, the activation of gas phase oxygen is limited in the lowtemperature activity range $\left(80-164^{\circ} \mathrm{C}\right)$. The support-induced modification of $\mathrm{Pd}^{0}$ limits the $\mathrm{H}_{2}$ consumption but, nevertheless, enables the $\mathrm{H}$-assisted $\mathrm{NO}$ dissociation via $\mathrm{Pd}^{0}-\mathrm{NO}$ intermediates. The temperature window of optimum performance is small. At higher reaction temperatures $\mathrm{NO}_{2}$ and $\mathrm{N}_{2} \mathrm{O}$ are produced by thermal decomposition of surface nitrates, with deterioration of $\mathrm{N}_{2}$ selectivity. At this range the support starts to become active as well. 


\section{Acknowledgement}

This work was financially supported by the National Natural Science Foundation of China (20573059, 20703057).

\section{References}

[1] H. Bosch, F. Jassen, Catal. Today 2 (1988) 369.

[2] P.L.T. Gabrielsson, Topics Catal. 28 (2004) 177.

[3] K. Yokota, M. Fukui, T. Tanaka, Appl. Surf. Catal. 121/122 (1997) 273.

[4] R. Burch, M.D. Coleman, Appl. Catal. B 23 (1999) 115.

[5] R. Burch, A.A. Shestov, J.A. Sullivan, J. Catal. 188 (1999) 69.

[6] M. Machida, S. Ikeda, D. Kurogi, T. Kijima, Appl. Catal. B 35 (2001) 107.

[7] C.N. Costa, V.N. Stathopoulos, V.C. Belessi, A.M. Efstathiou, J. Catal. 197 (2001) 350.

[8] M. Machida, T. Watanabe, Appl. Catal. B 52 (2004) 281.

[9] J. Shibata, M. Hashmoto, K. Shimizu, H. Yoshida, T. Hattori, A. Satsuma, J. Phys. Chem. B 108 (2004) 18327.

[10] S. Hamada, K. Ikeue, M. Machida, Appl. Catal. B 71 (2006) 1.
11] N. Macleod, R. Cropley, R.M. Lambert, Catal. Lett. 86 (2003) 69

[12] J.B. Yang, O.Z. Fu, D.Y. Wu, S.D. Wang, Appl. Catal. B 49 (2004) 61.

[13] N. Macleod, R.M. Lambert, Catal. Lett. 90 (2003) 111

14] G. Qi, R.T. Yang, F.C. Rinaldi, J. Catal. 237 (2006) 381

[15] Q. Chen, W. Zhou, G.H. Du, L.M. Peng, Adv. Mater. 14 (2002) 1208.

[16] G.H. Du, Q. Chen, P.D. Han, Y. Yu, L.M. Peng, Phys. Rev. B 67 (2003) 035323-1.

[17] C.E. Bamberger, G.M. Begun, C.S. MacDougall, Appl. Spectrosc. 44 (1990) 30.

18] S. Anderson, A.D. Wadsley, Nature 187 (1960) 499.

[19] T. Sasaki, Y. Komatsu, Y. Fujiki, Chem. Mater. 4 (1992) 894.

[20] H.Q. Zhu, Z.F. Qin, W.J. Shan, W.J. Shen, J.G. Wang, J. Catal. 225 (2004) 267.

[21] M.A. Debeila, N.J. Coville, M.S. Scurrell, G.R. Hearne, Appl. Catal. A 291 (2005)

[22] K. Hadjiivanov, H. Knozinger, Phys. Chem. Chem. Phys. 2 (2000) 2803.

[23] A.L. Goodman, E.T. Bernard, V.H. Grassian, J. Phys. Chem. A 105 (2001) 6443.

[24] S.W. Jorgensen, N.D.S. Canning, R.J. Madix, A. Hreels, Surf. Sci. 179 (1987) 322

[25] W.S. Epling, L.E. Campbell, A. Yezerets, N.W. Currier, J.E. Parks II, Catal. Rev. Sci. Eng. 46 (2004) 163.

[26] M.M. Wolf, H. Zhu, W.H. Green, G.S. Jackson, Appl. Catal. A: Gen. 244 (2003) 323.

[27] Z. Liu, J.A. Anderson, J. Catal. 224 (2004) 18. 